\title{
PIDANA PENJARA SEUMUR HIDUP ATAU PIDANA MATI (KONFIGURASI DILEMATIS ANTARA HUKUM DAN KEMANUSIAAN)
}

\author{
I.G.A.A Fitria Chandrawati, Kejaksaan Negeri Denpasar, \\ E-mail : ria.dhrista@gmail.com
}

doi: https://doi.org/10.24843/KS.2020.v08.i12.p15

\begin{abstract}
ABSTRAK
Tujuan Penelitian adalah untuk menganalisis sanksi pidana penjara seumur hidup menjadi alternatif dari penjatuhan sanksi pidana mati dan mengidentifikasi esensi antara pidana penjara seumur hidup dengan pidana mati. Penelitian ini memakai jenis penelitian hukum normative dengan pendekatan perundang-undangan, pendekatan historis dan kasus. Dengan ditunjang bahan hukum primer beberapa undang - undang yang menganut penerapan pidana mati, bahan sekunder teks - buku - buku hukum pidana, bahan jurnal - jurnal hukum, bahan tersier, kamus, ensiklopedi, harian surat kabar, teknis analisis deskriptif interpretatif - evaluatif argumentatif. Dengan simpulan temuan bahwa pidana penjara seumur hidup sering sebagai alternatif (pengganti) dari pidana mati guna menghindari kekeliruan dalam penjatuhan sanksi, juga untuk menghargai hak hidup seseorang sesuai prinsip HAM. Esensi pidana penjara seumur hidup dibandingkan dengan pidana mati sama - sama menyebabkan penderitaan fisik dan psikis bagi terpidananya, sanksi pidana tetap menimbulkan rasa derita, pembalasan dan sebagai bentuk pertanggung jawaban hukum bagi pelaku tindak pidana.
\end{abstract}

Kata Kunci : Penjara Seumur Hidup, Pidana Mati, Dilematis, Hukum dan Kemanusiaan

\begin{abstract}
The aim of this research is to analyze life criminal law into criminal sanctions and verified life imprisonment. This research using a type of normative legal research with an approach legislation, historical approach and case approach. With supported by primary legal material several laws that adhere application of capital punishment, secondary legal materials in the form of texts, books criminal law, legal journals, tertiary material in the form of dictionaries, encyclopedias, daily newspapers and using material analysis techniques law in the form of descriptive analysis techniques interpretative-evaluativeargumentative, with the conclusion that life imprisonment often as an alternative (substitute) to capital punishment to avoid mistakes in imposing sanctions, too to better respect the right to life of a person according to human rights principles. Essence life imprisonment compared to capital punishment together causing physical and psychological suffering for the conviction, sanctions crime still causes pain, retribution and forms legal liability for perpetrators of criminal acts.
\end{abstract}

Keywords : Life Imprisonment, Capital Punishment, Dilemma, Law and Humanity

\section{Pendahuluan}

\subsection{Latar Belakang Masalah}

Kiprah manusia alam kehidupannya akan ditentukan oleh perbuatannya sendiri. Tindakan apapun yang dilakukan tiap orang tanpa kecuali akan diatur dan pasti dihadapan dengan hukum. Kelahiran manusia ke dunia diikuti bekal berupa hak dan kewajiban secara krodati yang diberikan sang pencipta-Nya diserahkan kepada negara melalui primus inerparesinya memimpin dan mengelola semua individu individu dalam sebuah negara dengan bentuk dan type pemerintahan yang 
diinginkannya. Terlebih lagi bila bentuk negara dengan pemerintahan sistem demokrasi dengan type negara hukum kesejahteraan (law welfare states).

Manusia akan dihadapkan dengan salah satu cabanghukum yakni hukum pidana, bila ia terbukti dinyatakan bersalah melakukan suatu tindak pidana melalui peradilan pidana. Hukum pidana telah mengatur kualifikasi atas delik umum dan khusus. Bila terjadi pelanggaran atas ketentuanhukum pidana materiil, akan diselesaikan melalui tataran proses hukum formil yang tersedia. Hukum pidana telah mengkonsepsi adanya sanksi sebgai reaksi atas delik yang terjadi. Sanksi pidana terbai atas jenis sanksi (strafsoort), lamanya sanksi pidana (strafmaat) dan pelaksanaan atas pidana (staaf modus).

Terkait dengan perbuatan pidana (straf baarfeit) yang disangkakan paa pelaku akan berhadapan fungsi hukum pidana yang paling menentukan berupa penjatuhan akan sanksi pada pelakunya sebagai reaksi atas delik yang terjadi. Dalam hukum pidana materiil (KUHP) ditetapkan adanya pidana pokok seperti : pidana mati, pidana penjara, pidana kurungan, pidana denda dan pidana tutupan. Jenis pidana yang akan penulis kaji dan analisis dalam penelitian hukum normatif disini adalah jenis sanksi pidana penjara seumur hidup dan sanksi pidana mati, yang dalam masyarakat the manin the street (masyarakat luas dan awam hukum) menyebutnya dengan istilah "hukuman mati".

Berbicara lapangan hukum yang satu ini (hukum pidana) adalah merupakan salah satu cabang ilmu hukum yang memiliki fungsi utama atau istimewa (primum remidium) serta penggunaannya diperankan ketika lapangan / cabang ilmu hukum, lamanya sudah tidak dapat menyelesaikannya, barulah nantinya hukum pidana yang difungsikan sebgai jalan terakhir (obat terakhir) atau ultimum remidium. Karena mengingat sifat dan karakter hukum pidana adalah hukum yang menciptakan rasa derita, penderitaan, berupa pembalasan. Hukum pidana itu pada hakekatnya tidak lain daripada suatu hukum membalas dendam. ${ }^{1}$ Sanksi pidana pokok jenis pidana penjara dengan kualitifkasi seumur hidup seperti diatur pada Pasal 12 ayat (1) KUHP sering menjadi pilihan pertimbangan bagi hakim atau alternatif ketimbang memidana dengan pidana mati. Pidana penjara seumur hidup sebagai jenis pidana hilang kemerdekaan jangka panjang tidak berkesudahan kecuali terpidananya meninggal di ruang sel penahanannya. Berbeda dengan sanksi pidana mati tinggal menunggu eksekusi dari jaksa setelah putusan pengadilan berkekuatan hukum tetap (inkracht van geweijsde). Namun kedua sifat sanksi tersebut mengandung rasa penderitaan psikis dan fisik yang sama. Pidana penjara seumur hidup bagi terpidananya seolah-olah menunggu sesuatu tanpa tujuan dan harapan yang menjanjikan, kecuali ada perbaikan nasib keberuntungan melalui sarana hukum luar biasa seperti Peninjauan Kembali (PK) dari Mahkamah Agung (MA) dan / atau grasi dari Presiden, begitu pula sama halnya dengan terpidana dengan vonis pidana mati tersebut sangat kecil harapan kemungkinan akan adanya perobahan jenis pidana kedua jenis sanksi pidana dimaksud. Karena secara fakta yuridis dan kasus tindak pidana sampai hakim yang menjatuhkan pidana penjara seumur hidup atau pidana mati jelas ratio decidendi dan ratio legis dari hakim sudah sangat matang dan mempertimbangkan dari segala aspek seperti kepentingan hukum, kepentingan korban, pelaku sendiri serta kegunaan yang lebih luas yakni masyarakat. Sudah menjadi fakta hukum bahwa terpidana dijatuhi dengan alternatif utama jenis tersebut secara faktual aspek pertimbangan utama berupa dari modus operandi pelaku melakukan tindakan pidananya, tingkat sadisme,

${ }^{1}$ Roeslan Saleh (I), Masalah Pidana Mati, Aksara Baru, Jakarta, 1978, h. 11 
unsur perencanaan, keadaan korban - korbannya atau keluarga korban, dampak atau efek yang ditimbulkan, dilakukan dengan didahului, diikuti dengan kekerasan, ancaman teror yang menimbulkan rasa takut berkepanjangan dan lain-lain. Belakangan berkembang ada klasifikasi tindak pidana umum dan tindak pidana khusus bila dilakukan pelaku menjadi atensi penegak hukum seperti jaksa dan hakim untuk merencanakan tuntutan (bagi jaksa) memutus dengan pidana berat diantaranya jenis pidana mati atau alternatif yang dianggap masih lebih mausiawi memidana dengan pidana penjara seumur hidup.

Pergulatan hukum pidana dengan sanksinya yang begitu dipandang menyakitkan, menderitakan dihadapkan dengan adanya keharusan menegakkan hukum demi keadilan, kepastian serta kemanfaatan. Di lain sisi dihadapkan dengan esensi nyawa manusia yang memiliki hak hidup, namun pelaku tindak pidana telah menodai keajegan hukum pidana. Fenomena dilematis seperti itu solusinya mesti mengutamakan penegakan hukum demi keadilan dan tegaknya hukum walaupun langit akan runtuh (viat justisia viat coelum). Dalam penjatuhan sanksi pidana berat baik alternatif dengan pilihan pidana penjara seumur hidup ataupun meskipun harus dieksekusi mati sekalipun, pertimbangannya dari kualifikasi tindak pidana yang sifatnya sangat luar biasa (extra ordinary crimes) saat ini menjadi pertimbagnan dominan guna menjatuhkan salah satu dari kedua pidana pokok diatas. Jenis kejahatan di luar KUHP atau kejahatan tergolong tindak pidana khusus yang selanjutnya diberi klarifikasi kejahatan atau tindak pidana luar biasa (extraordinary crimes) dengan ciri ciri : kejahatan sebagai musuh umat manusia (hostes humanis generis), kejahatan terhadap kemanusiaan (crimes against humanity), kejahatan terhadap peradaban umat manusia (crime against sivilzation), kejahatan tergolong serius (seriously crime), tanpa memandang korbannya (crimes without victim), kejahatan lintas negara yang terorganisasi (transnasonal crime), kejahatan balas dendam (hate crime). Secara faktual jenis kejahatan diatas yang berkembang belakangan ini dalam bentuk kejahatan terorisme, narkotika dan psikotropika, korupsi, genosida dan kejahatan kemanusiaan berat dan lain-lain. Sedangkan dalam penegakan hukum pidana materiil (ius poenendi) oleh hukum pidana formil (ius poenale) terhadap kejahatan berat berupa hilangnya nyawa manusia yang dilakukan secara berencana : atau modus operandi dilakukan secara masif, sistematik / terstruktur. Type serta modus kejahatan kejahatan seperti diatas adalah layak para pelakunya diberi sanksi pidana berat sebagai imbalan atas akibat dari perbuatan yang telah mereka lakukan. Pemberian sanksi pidana berat tersebut sesuai dengan konsepsi filosofi pemidanaan serta salah satu tujuan pemidanaan yang dikonsep oleh Suititus Reid bahwa ada 4 (empat) unsur sebagai justifikasi pemidanaan yakni terdiri dari : rehabilitation, incapacitation, deterence dan retribution. ${ }^{2}$ (perbaikan, melayani, pencegahan dan pembalasan). Unsur terakhir berupa pembalasan (retribution) atau vergelding layak ditempatkan pada pelaku tindak pidana berat tersebut.

Penjatuhan sanksi pidana berat (baik pidana penjara seumur hidup ataupun sanksi pidana mati tersebut guna tegaknya asas legalitas tadi dalam "geen straf zonder shuld", terhadap pelaku kejahatan. Karena sanksi pidana menurut herbert L. Packer, ${ }^{3}$ dinyatakan : sampai kapanpun sanksi pidana tetap diperlukan, merupakan sarana atau

\footnotetext{
2 Sue Titus Reid, Criminal Justice Procedure and Issues, West - Publishing Company, New York, 1978, p. 347

${ }^{3}$ Herbert L. Packer, The Limits of Criminal Sanction, Stamford University, California, 1968, p. 368
} 
alat terbaik untuk menghadapi bahaya - bahaya besar, dan sebagai pengancam yang utama dari kelebeihan manusia. Maka bila dihubungkan pendapat Pcaker diatas tentang urgensinya sanksi pidana sepanjang jaman yang tidak dibatasi oleh ruang, waktu dan tindak pidana umum maupun khusus, maka dapat dilegalkan dan ada dasar pembenar (justifikasi) kuat bahwa tindak pidana yang masuk klasifikasi berat atau serius adalah wajar dipidana dengan sanksi pidana setimpal breat seperti sanksi pidana penjara seumur hidup ataupun sanksi pidana mati. Sebagai implementasi fenomena diatas tersurat dan tersirat bahwa pemidanaan berat seperti pada Bab VII titel ketentuan pidana Pasal 36 Undang - Undang Republik Indoneisa Nomor 26 Tahun 2000 tentang Pengadilan Hak Asasi Manusia (HAM) pada intinya bahwa setiap orang yang melakukan perbuatan sebagaimana dimaksud dalam Pasal 8 huruf a, b, c, d atau e (perbuatan genosida) di pidana dengan pidana mati atau pidana penjara seumur hidup atau pidana penjara paling lama 25 (dua puluh lima) tahun atau paling singkat 10 (sepuluh) tahun. Kalau dicermati serta direnungkan konsep pemidanaan pada pengadilan retributif pada pelaku pelanggaran HAM berat. Sanksi pidana penjara seumur hidup ataupun pidana mati telah menghadap di depan mata sang pelaku. Walaupun bagi negara Indonesia masih terdapat 2 (dua) kelompok masyarakat antara pro dan kontra (kelompok retensionis dan kelompok abolisionis) terhadap pelaksanaan pidana mati atau dalam masyarakat luas lebih sering mengistilahkan dengan hukuman mati, seperti pandangan Hendarman Supanji ${ }^{4}$ yang lebih dominan pendapatnya bahwa pidana mati di Indonesia masih diperlukan terhadap kasus kasus tertentu yang sifatnya kejahatan luar biasa (extra ordinary crimes) seperti tindak pidana terorisme, penyalahgunaan obat - obatan terlarang (narkoba), dan psikotropika, pembunuhan berencana dan kejahatan kemanusiaan dalam lingkup pelanggaran HAM (Hak Asasi Manusia). Hal senada juga disampaikan oleh Woro, Winandi dan Indra, ${ }^{5}$ bahwa pelaku tindak pidana narkotika bagi para pengedarnya layak untuk dijatuhi sanksi pidana mati.

Fungsi dan tujuan hukum pada intinya adalah guna ketertiban masyarakatnya. Sesuai pula dari sifat hukum yakni memaksa dan mengatur. Terlebih fungsi tindak pidana melalui sanksi yang dilimpahkan pada pelaku tindak pidana tidak dapat ditawar - tawar, paling tidak dalam pertimbangan hukumnya sebelum putusan dijatuhkan hakim ada hal - hal ratio legis meringankan dan memberatkan peradilan pidana ke depan telah menstimulir ide keseimbangan dalam penjatuhan sanksi pidana seperti yang dikonsepsi oleh Muladi. ${ }^{6}$ Adanya 3 (tiga) elemen penting dalam hukum pidana berupa : daad - daer - straafrecht, sehingga proses peradilan melindungi kepentingan dan keperluan semua pihak seperti mempertimbangkan perbuatan (delik), kondisi dan posisi pelaku / pembuat delik dan terakhir pertimbangan akan sanksi / ancaman pidana pada pelakunya.

Konsep diatas menyangkut keseimbangan suatu ide yang diarahkan pada pembaharuan peradilan pidana terutama menyangkut sanksi pidana khususnya keberadaan sanksi pidana penjara jangka panjang dari hilangnya kemerdekaan seseorang apalagi di pidana mati, maka hak-hak kodrati secara alamiah manusia mesti

4 Supanji, Hendarman, Eksistensi Pidana Mati Dalam Proses Penegakan Hukum di Indonesia, Jurnal Kajian Wilayah Eropa, Volume IV, Nomor 2 Tahun 2008, h. 78.

5 Woro, Winandi dan Indra Rukmana Lukito, Penjatuhan Pidana Mati Dalam Tindak Pidana Narkotika, Jurnal Hukum, Volume XIX Nomor 19, Oktober 2010

${ }^{6}$ Muladi, Demokratisasi, Hak Asas Manusia dan Reformasi Hukum di Indonesia, The Habibie Centre, Jakarta, 2002, h. 28 
dipertimbangkan dari aspek filosofi pidana mati itu, keuntungan dan kerugiannya, pemberitaan panjang ketika menjalani masa tunggu eksekusi dari si terpidananya. Semua itu menurut : Kuat Yudi Prayitno mesti mempertimbangkan aspek restorative justice dalam penegakan hukumnya. ${ }^{7}$

Penegakkan hukum dihadapkan dengan konsep restrorative justice dalam peradilan pidana tampaknya akan kecenderungan adanya pelemahan terhadap eksistensi beberapa asas seperti asas legalitas, asas kepastian hukum, asas kesalahan serta prinsip dari rechts idenya hukum berupa keadilan kemanfaatan dan kepastian kembali dihubungkan dengan pemidanaan menurut Achmad Ali, ${ }^{8}$ pemidanaan termasuk dialamnya pidana mati dimaksudkan untuk mewujudkan tujuan hukum yaitu kedamaian (peace), keadilan (justice), kemanfaatan (utility) dan kepastian (certainty).

\subsection{Rumusan Masalah}

Perumusan masalah pada penelitian ini adalah Apakah sanksi pidana penjara seumur hidup menjadi alternatif dari penjatuhan sanksi pidana mati ? dan Apakah tidak sama esensi antara pidana penjara seumur hidup dengan pidana mati ?

\subsection{Tujuan penelitian}

Tujuan Penelitian adalah untuk menganalisis sanksi pidana penjara seumur hidup menjadi alternatif dari penjatuhan sanksi pidana mati dan mengidentifikasi esensi antara pidana penjara seumur hidup dengan pidana mati.

\section{METODE PENELITIAN}

Metode penelitian yang digunakan adalah jenis penelitian hukum normatif. Penelitian hukum normatif (normative legal research) merupakan penelitian yang dilakukan dengan cara mengkaji peraturan perundang-undangan yang berlaku atau diterapkan terhadap suatu permasalahan hukum tertentu. Penelitian hukum normatif meneliti hukum dari perspektif internal dengan objek penelitiannya adalah norma hukum. ${ }^{9}$ Penelitian normatif seringkali disebut dengan penelitian doktrinal, yaitu penelitian yang objek kajiannya adalah dokumen peraturan perundang-undangan dan bahan pustaka. ${ }^{10}$

\section{HASIL DAN PEMBAHASAN}

3.1. Komparasi Kelebihan dan Kekurangan Antara Sanksi Pidana Penjara Seumur Hidup Dengan Sanksi Pidana Mati

\subsubsection{Konsep Sanksi Pidana Penjara Seumur Hidup}

Pengaturan sanksi pidana penjara seumur hidup termuat secara ringkas dalam Pasal 12 ayat (1) KUHP yakni : "Pidana penjara adalah seumur hidup atau selama waktu tertentu". Khusus yang akan dikaji disini adalah pidana penjara seumur hidup. Batasan pengertian pidana seumur hidup secara batasan legal formalnya tidak ada

7 Kuat Yudi Prayitno, Restorative Justice Untuk Peradilan di Indonesia (Perspektif Yuridis Filosofis Dalam Penegakan Hukum In Conkreto), dalam : Jurnal Dinamika Hukum, Volume 12 Nomor 3, September 2012, h. 410

8 Achmad Ali, , Menguak Realitas Hukum, Prenada Media Group, Jakarta, 2008, 81

9 I Made Pasek Diantha. Metodologi Penelitian Hukum Normatif dalam Justifikasi Teori Hukum. Jakarta: Prenada Media Group, 2017. h.12.

10 Peter Mahmud Marzuki. Penelitian Hukum. Jakarta: Kencana Prenida Media, 2011. h.34. 
mengatur dalam perundang-undangan pidana Indonesia. Anggapan masyarakat umum di kalangan awam hukum istilah seumur hidup sering diartikan sebagai sama dengan umur hidupnya pelaku ketika vonis hakim dijatuhkan, misalnya ketika pelaku suatu tindak pidana disidangkan berumur 35 (tiga puluh lima) tahun, atau pidana yang dijatuhkan adalah sama dengan usia umur pelaku pada saat melakukan tindakan pidana yaitu 35 (tiga puluh lima) tahun.

Akan berbeda pemahaman terhadap pengertian pidana penjara dari kalangan ahli hukum / doktrin seperti Roeslan Saleh ${ }^{11}$ dan Achmad Ali12 menyatakan bahwa pengertian pidana penjara seumur hidup itu si terpidana mengalami masa waktu hukumannya sampai sepanjang hidupnya (atau terpidana berada di tahan penjara sampai maut kematian menjemputnya dari sang kuasa). Maka dihubungkan dengan pengaturan KUHP menyangkut pidana penjara seumur hidup menganut sistem (straf soort) ditentukan secara pasti (definite sentence) karena terpidana dikenakan jangka waktu yang pasti (a definite period of time) yaitu menjalani pidana sepanjang hidupnya. ${ }^{13}$

Anggapan bahwa dengan penjatuhan pidana penjara seumur hidup tersebut pada awalnya muncul pandangan beragam dari masyarakat luas, dengan menyatakan keprihatinannya bahwa si terpidana telah kehilangan semua harapannya, karena ia terkurung selamanya dalam tahanan penjara dan pula tidak dapat lagi bergabung ke dalam lingkungan keluarga ataupun masyarakatnya yaitu menjalani pidana sepanjang hayat di kandung badan. Disinilah letak esensi filosofi jiwa manusia dipertaruhkan guna mempertanggungjawabkan perbuatan yang telah ia lakukan di hadapan keperkasaan hukum. Namun dihadapan proses hukum, jiwa dan naluri hukum yang melekat tidak sebengis dan sekejam karakter penjahat kambuhan, esensi dan makna hukum juga dalam keadaan situasi sesulit dan seberat apapun sanksi harus ditempatkan kepada pelaku kejahatan, hukum juga menyediakan sarana guna memperingan, mengurangi bahkan, untuk merobah putusan hukum itu sendiri berupa bagi seorang terpidana dijatuhi pidana terberat sekalipun masih ada dicanangakan upaya - upaya hukum yang sifatnya luar biasa dan istimewa seperti peninjauan kembai (PK), kasasi demi kepentingan hukum oleh Jaksa Agung dan terakhir hak prerogatif dari Presiden berupa grasi.

Namun semua upaya hukum dan sarana hukum yang tersedia itu melalui syarat - syarat yang diatur oleh aturan hukum pula secara teknis pelaksanaannya dalam pengurangan masa pemidanaan tersebut mulai dari adanya remisi (umum, khusus dan istimewa), asimilasi pelepasan bersyarat / bebas bersyarat dan grasi yang berupa perubahan masa pidana seperti dari pidana penjara seumur hidup menjadi pidana dengan lama waktu tertentu yang ditetapkan, misalnya menjadi pidana penjara 20 (dua puluh) tahun atau 15 (lima belas) tahun. Keluwesan ketentuan hukum tersebut guna memberikan peluang bagi terpidana penjara jangka panjang itu selalu mengalami perkembangan perobahan ketentuan, disesuaikan dengan situasi, kondisi, waktu serta keadaan kepentingan hukum oleh negara sendiri. Menurut B. Richards ${ }^{14}$ bahwa penghukuman penjara seumur hidup menjadi beban bagi terpidana, keluarganya termasuk pemerintah dalam membuatnya.

${ }^{11}$ Roeslan Saleh (II), Stelsel Pidana Indonesia, Aksara Baru, Jakarta, 1983, h. 22

12 Achmad Ali, Op Cit, h. 37

${ }^{13}$ Achmad Ali, Op Cit, h. 38

${ }^{14} \mathrm{~B}$. Richard, The Experience of Long Trem Imprissionment, British Journal of Criminology, Vol. 18, No. 2, 1978, p. 168 


\subsubsection{Kedudukan Pidana Penjara Seumur Hidup Serta Kelebihan dan Kelemahannya}

Kedudukan sanksi pidana penjara seumur hidup dalam kebijakan legislatif dan praktek dunia peradilan selama ini dimana jenis pidana penjara seumur hidup difungsikan sebagai "pidana pengganti" dari pidana mati. ${ }^{15}$ Hakim dalam memutus dan menetapkan terdakwanya dengan sanksi pidana penjara seumur hidup, dengan mengacu pula dari adanya dakwaan dan tuntutan (requisitoir) Jaksa Penuntut Umum yang biasanya didakwa secara berlapis mulai dari dakwaan primair dan subsidair dengan mengalir pada tuntutan yang esensinya sama primair dan subsidair. Bila hakim akan memutus terdakwanya dengan kualifikasi tidak pidananya serius dan tergolong berat pasti hakim akan menjatuhkan jenis pidana pokok maksimal seperti pidana mati. Namun atas pertimbangan ada hal-hal meringankan maka hakim akan mengikuti dakwaan subsidair dari jaksa dengan menjatuhkan sanksi pidana pokok berikutnya berupa pidana penjara seumur hidup, disinilah letak posisi pidana penjara seumur hidup sebagai pengganti pidana mati tersebut. Pertimbangan kemanusiaan yang dibungkus dalam esensi HAM dominan menjadi bahan pertimbangan hakim sehingga tidak sampai pada sanksi pencabut nyawa alias pidana mati atau hukuman mati bagi terdakwanya. Pertimbangan aspek kemanusiaan seperti itu sejalan dengan pandangan Heiner Bielfeldt ${ }^{16}$ yang pada intinya HAM (Hak Asasi Manusia) di dunia barat dihadapkan dengan prinsip ajaran agama tertentu dalam menjustifikasi antara hukum dengan hidup matinya manusia.

Tampak adanya berbagai kelemahan dan beberapa kelebihan dihadapan hukum dan masyarakat luas dari adanya sanksi pidana penjara seumur hidup ini sebagai pengganti alternatif dari penjatuhan pidana mati atau lazimnya diistilahkan dengan penghukuman mati tersebut.

\subsubsection{Kelemahan Pidana Penjara Seumur Hidup dan Pidana Mati Perspektif Hukum dan Hak Asasi Manusia (HAM)}

1. Bagi terpidana seumur hidup tertutup kemungkinan mendapat pelepasan bersyarat (karena Pasal 15 KUHP tidak mengatur bagi narapidana seumur hidup untuk dapat pelepasan bersyarat) karena Pasal 15 secara jelas menyatakan "Jika terpidana telah menjalani dua pertiga (2/3) dari lamanya pidana penjara yang dijatuhkan kepadanya dapat diberikan pelepasan bersyarat".

2. Tindak pidana yang diancam dengan pidana seumur hidup dalam KUHP adalah yang dikualifikasi sebagai "kejahatan berat" (kualifikasi tindak pidana berat belum / tidak pasti / belum ada kriteria secara yuridis formal) - norma kabur dengan luas - dalam Buku II KUHP dimuat dalam 8 Bab dan 23 Ketentuan (Perkembangan Kejahatan Tindak Pidana dengan kualifikasi berat berkembang pesat seperti dalam berbagai tindak pidana khusus).

3. Penjatuhan pidana seumur hidup difungsikan sebagai pidana pengganti (subsidair) dari penjatuhan pidana mati. Hal demikian akan menambah volume penjatuhan pidana seumur hidup tersebut, mengingat masih tingginya /

15 Barda Nawawi Arief, Bunga Rampai Kebijakan Hukum Pidana, PT. Citra Aditya Bakati, Bandung, 2002, h. 207.

16Heiner Bielefeldt, "Hak Asasi Manusia : Benturan Antara Barat dan Islam", dalam Jurnal : Wacana Hak Asasi Manusia Antara Skenario Kemanusiaan dan Proyek Global, Edisi 8, Tahun II, Inssit. Press, Yogyakarta, h. 13 
banyaknya pihak - pihak tidak setuju akan penjatuhan pidana mati tersebut, maka sebagai alternatifnya hakim akan menjatuhkan jenis pidana penjara seumur hidup terhadap tindak pidana tergolong berat dan yang sangat merugikan masyarakat luas (pro dan kontra pidana mati terutama kelompok abolisionis - alternatifnya pada jenis pidana seumur hidup ini)

4. Munculnya gagasan kebijakan untuk menunda pelaksanaan pidana mati, hal demikian solusi hukumnya alternatif pilihannya pada pidana seumur hidup tersebut

5. Pidana seumur hidup pula menjadi alternatif dari pidana selama waktu tertentu dengan maksimal 20 tahun penjara bila ditambah lagi bagi pelaku tindak pidana yang melakukan tindak pidana lain dengan ancaman pidana berat pula serta tetap long residive / residivis sekaligus. Maka alternatif jenis pemidanaannya potensial pidana penjara / seumur hidup.

6. Secara teknis pembinaan bagi narapidana seumur hidup menjadi beban tanggung jawab LAPAS sekaligus negara sangat tinggi (waktu panjang, biaya rutin, membuat over capacity (over load).

7. Perspektif HAM (Hak Asasi Manusia) melanggar klasifikasi HAM (Hak Asasi Manusia) generasi I (kebebasan) kemerdekaan individu sebagai insan manusia terampas oleh sistem (pemidanaan / penitensier), dengan mengorbankan hak hak esensial manusia sebagai makhluk individu ciptaan Tuhan Yang Maha Esa, sekaligus pelanggaran akan hak-hak sipil yang tidak boleh dikurangi / dirampas (derogable rights) oleh siapapun termasuk oleh negara sekalipun.

8. Batas waktu "seumur hidup" tidak diketahui oleh manusia, rahasia batasan waktu kehidupan merupakan domain sang pencipta-Nya, maka pula tidak dapat ditentukan batasan 2/3 (dua per tiga) tersebut bila dikaitkan dengan salah satu hak terpidana untuk memperoleh pelepasan bersyarat tersebut.

9. Bagi terpidana seumur hidup hak untuk mendapatkan remisi (bagi narapidana yang telah berlakuan baik sebagai salah satu syarat) juga tertutup, kecuali pidana seumur hidup mendapatkan perobahan dari upaya hukum tertentu.

10. Pidana penjara seumur hidup bagi terpidananya menjalani kehidupan tanpa harapan ke depan, akan menghilangkan rasa taubat, karena harapan untuk menjalani hidup ke tengah-tengah masyarakat terutama lingkungan keluarga yang dicintainya tidak mungkin terlaksana lagi, akankah ada datang malaikat penyelamat dan pembuka gerbang terali besi yang telah membelenggunya sampai maut mejemputnya?

11. Terpidana seumur hidup tidak mungkin untuk memperoleh ijin asimilasi, karena ketentuan hukum positif telah memangkasnya, keputusan Menteri Kehakiman Republik Indonesia Nomor : M.01.PR.01.10 Tahun 1989 menyatakan antara lain "Bahwa persyaratan substantif bagi seorang narapidana untuk dapat ijin asimilasi telah menjalani $(1 / 2)$ dari masa pidananya. Terkait masa pidana (straf maat) terpidana seumur hidup yang tidak diketahui angka nominal maksimalnya, berarti angka $1 / 2$ (setengah) sebagai pedoman syarat tidak pernah akan diketahui oleh siapapun sebagai manusia biasa.

12. Masih dianut diterapkannya pidana penjara seumur hidup bagi Indonesia dalam berbagai kebijakan hukum presitif (ius operatum - ius constitutum) untuk memproses pelaku tindak pidana diakhir sistem bekerjanya sistem peradilan pidana, menandakan bahwa ada kecenderungan mengabaikan perlindungan terhadap individu sebagai pelaku tindak pidana, hal demikian bertentangan dengan esensi nilai-nilai prinsipal yang hidup dalam masyarakat Indonesia selalu 
mengutamakan keseimbangan tampak pula aplikasi teori pemidanaan berpangkal pembalasan (abolutisme) sangat menonjol nilai - nilai humanisme tampak dikesampingkan.

13. Pidana penjara seumur hidup sebagai pilihan (alternatif) dibanding menjatuhi dengan pidana mati atau pencabutan nyawa yang tidak mungkin dapat dikoreksi. Dan kesempatan taubat untuk merobah perilaku sudah tidak ada peluang kesempatan lagi. Walaupun divonis dengan pidana hilang kemerdekaan jangka panjang malah abadi, dan tinggal menunggu kematiannya, namun masih ada proses waktu untuk merenung, mengkoreksi diri atas perbuatan yang telah ia lakukan dimasa lalu. Menimang - nimang akan akibat bagi korbannya (victim), keluarga korban, masyarakat sekitar akan dampak yang ditimbulkan ulah perbuatannya sendiri. Memang penyesalan selalu datang terlambat, tetapi paling tidak rasa penyesalan sebagai sarana untuk taubat mohon ampun dan maaf kepada semua pihak yang dirugikan dari ulah perbuatan yang telah terjadi di masa silam.

14. Adanya konstruksi hukum dalam hukum positif Indonesia dengan adanya pembatasan hak pengajuan upaya hukum luar biasa seperti Peninjauan Kembali (PK) terhadap putusan yang telah memiliki kekuatan hukum tetap (PK) yang hanya dapat dimohon oleh terpidana atau ahli warisnya (Pasal 263 ayat (1) KUHAP. Ketentuan Mahkamah Agung (MA) dengan SEMA nomor 7 Tahun 2014 tentang Batasan Peninjauan Kembali (PK) akan membatasi ruang gerak pemohon PK (Peninjauan Kembali) yang tidak dapat diajukan permohonan berkali - kali kepada Mahkamah Agung (MA) yang hanya dapat 1 (satu) kali guna berkeinginan untuk memperbaiki nasib dari masa pidana penjara seumur hidup untuk bisa menjadi pidana penjara dalam kurun waktu tertentu. Begitu pula halnya bagi terpidana mati lainnya tetap menunggu putusan dari Presiden bila terpidananya mengajukan permohonan upaya hukum istimewa berupa grasi.

15. Adanya pula konstruksi hukum dalam hukum positif Indonesia setelah bergantinya Undang - Undang Grasi Nomor 22 Tahun 2002 dengan Undang Undang Nomor 5 Tahun 2010 tentang Grasi bahwa pengajuan permohonan grasi dari terpidana ataupun kuasanya saat ini hanya dapat dimohon satu kali saja. Berbeda dengan pengaturan undang - undang grasi sebelumnya (Undang Undang Nomor 22 Tahun 2002) bahwa permohonan grasi dapat dilakukan tiap dua tahun sekali setelah melewati batas waktu 2 (dua) tahun terpidana dapat kembali memohon pengajuan grasi kepada Presiden.

Bagi Indonesia penjatuhan sanksi pidana penjara seumur hidup oleh hakim secara historis kasus - kasus pidana yang telah dijatuhkan tidak terhitung jumlahnya terutama pelaku-pelaku tindak pidana umum makar, pencurian didahului, disertai dengan kekerasan yang sampai menimbulkan cacat fisik seumur hidup dan hilangnya nyawa. Begitu pula perkembangan dalam tindak pidana yang bersifat khusus seperti dalam kejahatan terorisme dan narkotika. Belakangan terpidana penjara seumur hidup telah tercatat dalam statistik kriminal penegakan hukum di Indonesia diantaranya seperti :

1. Putusan Kasasi MARI Nomor : 1348K/Pid./2005/ tanggal 12 september 2005 jo Putusan PK MARI Nomor : 271PK/Pid. Sus/2011 tanggal 15 Nopember 2013 jo Putusan PK tersebut terkait dengan kasus pembobolan Bank BNI 1946 dalam hal L/C fiktif a/n terdakwa Andrian Herling Woworuntu tahun 2005 - dengan pidana seumur hidup (telah inkracht). 
2. Keputusan Kasasi MARI Nomor : 336K/Pid.Sus/2015 tanggal 23 Pebruari 2015 kasus penanganan Pilkada di Mahmakah Agung (MA) atas kasus pilkada di beberapa daerah - terdakwa mantan Ketua MK (Mahkamah Konstitusi) a/n. Akil Mochtar Tahun 2015 dengan pidana penjara seumur hidup (putusan telah inkract) dalam kasus tindak pidana korupsi (gratifikasi)

3. Putusan Kasasi MARI Nomor : 363K/MIL/2017 tanggal 20 September 2017 - dalam perkara korupsi anggaran alat utama sistem persenjataan (ALUTSISTA) pada tahun 2010 - 2014 (salah satunya dalam pembelian Jet Tempur F-16 dan Helikopter Apache dengan terdakwa : Brigjen Teddy Hernayadi - (Mantan Kepala Bidang Pelaksanaan Pembiayaan Kementerian Pertahanan) - dijatuhi pidana seumur hidup (telah inkracht), dalam kasus tindak pidana korupsi.

4. Putusan pidana penjara seumur hidup atas terdakwa Ali Imron tahun 2003 dalam Kasus Terorisme Bom Bali I

5. Pembuuhan wartawan Jawa Pos / Radar Bali - tahun 2009 A. A. Gde Bagus Narendra Prabangsa oleh Nyoman Susrama vonis Pengadilan Negeri Denpasar memidana penjara seumur hidup yang sempat Presiden mengeluarkan Keppres Nomor 29 Tahun 2018 tentang Remisi yang diajukan terpidana dengan isi merobah pidana seumur hidup menjadi 20 tahun (akhirnya Keppres dicabut kembali karena mendapat protes tidak setuju atas remisi Presiden c/q. Menteri Hukum dan HAM). Tidak berhenti sampai disana usaha terpidana penjara seumur hidup Nyoman Susrama yang menjalani masa pidana di RUTAN / LAPAS KLS II Bangli, pada awal April tahun 2020 dengan memanfaatkan keluarnya peaturan Menteri Hukum dan HAM (Hak Asasi Manusia) Republik Indonesia Nomor 10 Tahun 2020 tentang Pemberian Lepas Bersyarat melalui asimilasi dan intergrasi sejumlah 30.000 (tiga puluh ribu) orang di seluruh LAPAS Indonesia warga binaan (narapiana) yang menjalani masa pidana dibawah 5 (lima) tahun dalam kejahatan / tindak pidana umum, dibawah pengawasan Institusi Departemen Hukum dan HAM. Permohonan terpidana ini masih ditanggapi dingin oleh pemerintah. ${ }^{17}$

\subsection{Pidana Mati atau Hukuman Mati Sebagai Jenis Sanksi Pidana Pokok Paling Utama}

\subsubsection{Pengaturan Jenis Sanksi (Straf Soort) Pidana Mati Dalam KUHP (Hukum} Pidana Materiil - KUHP)

Dalam KUHP Pasal 10 jenis sanksi dibagi 2 (dua) kategori yaitu pidana pokok dan pidana tambahan. Pidana pokok urutan penempatan pada urut pertama diposisikan pidana mati ini kemudian disusul dengan jenis saksi pokok lain seperti urutan ke-2 (kedua) sanksi pidana penjara (di dalamnya masuk pidana penjara seumur hidup) Pasal 12 ayat (1) KUHP. Pro dan kontra konsepsi sanksi pidana mati dari dinamika sejarahnya telah berlangsung ratusan tahun. Ada negara - negara yang tidak setuju dengan adanya pidana mati atau hukuman mati (tergolong kelompok abolisionis / penentang) dan berhadapan dengan kelompok retensionis dengan pertimbangan terjaminnya ketentraman masyrakat sebagai upaya pencegah (general prevention) dari timbulnya kejahatan. Kelompok abolisionis memandang pemidanaan dengan cabut nyawa ini bertentangan dengan syarat hidup mansia yang diberikan oleh Tuhan selaku pencipta kehidupan di alam raya ini, pertimbangan kemanusiaan sebagai hak hakiki dari kehidupan manusia yang menjadi komitmen universal pencetus dan

17 Dihimpun Penulis Dari Berbagai Sumber Seperti Yurisprudensi, Harian Surat Kabar Jawa Pos, Radar Bali, Dalam Beberapa Terbitan. 
pendukung lahirnya Generasi I HAM dengan derogable rights-nya yang paling hakiki hak untuk hidup.

Namun akan berbanding terbalik ketika seseorang secara sadar telah mengambil hak nyawa orang lain, apapun alasan mereka juga akan bertentangan dengan prinsip hidup orang lain itu. Disinilah muncul dilematis hukum dihadapkan dengan persoalan kemanusiaan tiap individu. Penegak hukum khususnya jaksa dan hakim akan mengambil jalan tengah seolah-olah menyampaikan esensi yang tegas tanpa kecuali, namun dilandasi rasa belas kasihan, demi menjunjung tinggi esensi kemanusiaan yang beradab, kemudian mengambil jalan tengah tidak dengan menghukum mati pelanggarnya, namun dengan memidana (oleh hakim) dengan pidana penjara seumur hidup.

Berbagai tindak pidana umum dalam KUHP sekarang masih mengancam pelakunya dengan pidana mati. Tercatat ada lebih kurang 7 (tujuh) jenis tindak pidana dalam KUHP yang mengancam pelakunya dengan sanksi pidana mati. Terutama bila delik - delik yang dilakukan pelaku dengan kualifikasi berat, dilakukan berencana (berkualifisir), dilakukan secara biadab diluar batas - batas perikemanusiaan, seperti diantaranya pembunuhan berencana diakhiri dengan modus mutilasi guna menghapus jejak pelakunya. Bagi terpidana mati akan sulit menghindar dari perbuatan sendiri yang telah ia lakukan kepada korbannya. Termasuk negara (Indonesia) hingga kini tetap berkomitment mempertahankan pidana mati ini. Pandangan doktrin / ahli hukum masih sebagian besar di Indonesia setuju akan pencantuman pidana mati ini termasuk penempatannya pada Rancangan / RUU KUHP nasioinal nanti. Pidana mati menempati porsi pasal tersendiri dengan beberapa lex spesialisnya. Dari beberapa pendapat hukum terkait dengan penjatuhan sanksi pidana mati ada 4 (empat) penulis / peneliti yang menyangkut pidana mati dalam masing-masing berbagai judul tulisannya yang pada intinya tetap setuju pencanangan pidana mati di Indonesia namun dengan berbagai alasan dan ratio legis guna menunjang penegakkan hukum seperti tulisan beserta pandangan - pandangannya dari : M. Ali Mahruz (Meninjau Ulang Positivisme Pidana Mati Antara Objectivisme dan Formalisme Hukum), Abdul Rahim dengan judul "Hukuman Mati Perspektif Relativisme HAM, Asruddin Azwar, dengan judul : "Implikasi International Hukuman Mati Terhadap Indonesia", Muhammad Hafiz dengan tulisan : "Prinsip Penerapan Terbatas dan Pengurangan Progresif Dalam Hukuman Mati", dan Satrio Wiataru, dengan judul "Hak Prosedural dan Upaya Hukum Terkait Pidana Hukuman Mati Dalam Perspektif Acara Pidana".18

\subsubsection{Perkembangan Konsep Pidana Mati di Luar KUHP Yang Tergolong Tindak Pidana Khusus}

Intensitas dan kapasitas kejahatan berkembang pesat ditunjang oleh kemajuan globalisasi modern di bidang ilmu pengetahuan dan teknologi canggih. Hukum pidana yang telah terkodifikasi kewalahan menampung jenis tindak pidana yang berkembang dan muncul setiap saat, bahkan dengan modus - modus baru serta type kejahatan tanpa memandang korban dan tidak dibatasi tempat (locus delicti) dan ruang waktu (tempus delicti). Bermunculanlah jenis kejahatan baru seperti kejahatan dunia maya (kejahatan cyber / cyber crimes) yang dapat terjadi merambah lintas batas negara

18 Jurnal Transisi, Media Penguatan Demokrasi Lokal, Edisi Nomor : 10/2015, ISSN : 1978 - 4287,Penerbit Instrans Instituete. 
(transnational crime) / kejahatan transnational bahkan dilakukan secara terorganisir (organized crime). Kejahatan yang tumbuh diluar KUHP jumlahnya sulit dihafal, seperti kejahatan terorisme, kejahatan korupsi, kejahatan peredaran gelap / terlarang narkotika dan psikotropika dan jenis kejahatan baru lainnya, yang kini diberi label kualifikasi kejahatan extra ordinary crimes (kejahatan luar biasa). Juga kejahatan kejahatan temporer diatas sudah menjadi komitmen dunia international untuk diperangi bersama oleh seluruh negara - negara beradab di muka bumi terutama negara - negara yang bernama dibawah bendera Perserikatan Bangsa - Bangsa (PBB).

Dalam beberapa konvensi international menyangkut pidana mati telah diakui dan mengaturnya, seperti Pasal 3 Deklarasi Universal Hak Asasi Manusia (HAM) 10 Desember 1948 menyatakan bahwa "Setiap orang berhak atas penghidupan, kebebasan dan keselamatan individu. ${ }^{19}$ Juga dalam Convenan International Hak - Hak Sipil dan Politik (ICCPR) Pasal 6 diantaranya adalah menyebutkan : "Setiap manusia berhak atas hak untuk hidup yang melekat pada dirinya. ${ }^{20}$ Namun hak hidup individu yang meletak sejak lahir itu tidak menutup kemungkinan dapat dicabut oleh hukum international bila melakukan kejahatan yang menjadi komitmen bersama negara beradab untuk memberantasnya.

Perbuatan yang dapat digolongkan sebagai kejahatan atau tindak pidana internastional selalu mengalami perkembangan. Menurut "Bassionuni" mengkualifikasikan ada 22 (dua puluh dua) perbuatan yang termasuk ke dalam tindak pidana internasional mulai dari tahun 1815 - 1984. ${ }^{21}$ Kesemuanya jenis tindak pidana itu tergolong kualifikasi berat, kualifikasi kejahatan serius, extra ordinasi crime, yang cenderung pemidanaannya bagi si pelaku cenderung dengan pidana berat seperti pidana seumur hidup. Jenis kejahatan dimaksud diatas diantaranya agresi, kejahatan perang, genosida, penyiksaan, pembajakan dan lain-lain. Bahkan jenis - jenis kejahatan seperti tersebut diatas sering dilakukan dan menyangkut kejahatan terorganisir lintas negara yang dipahami sebagai kejahatan serius (seriously crimes) yang sering dilakukan oleh kelompok pelaku tindak pidana terorganisasi. Yang menurut Tom Obokata mengutipnya dari UNCATOC tahun 2003 merumuskan pengertian "Kelompok pelaku tindak pidana terorganisasi adalah suatu kelompok terstruktur yang terdiri dari tiga orang atau lebih, terbentuk dalam suatu periode waktu dan bertindak secara terpadu dengan tujuan untuk melakukan satu tindak pidana serius satu pelanggaran atau lebih yang diatur dan ditetapkan menurut konvensi ini, untuk mendapatkan secara langsung atau tidak langsung keuntungan keuangan atau materi lainnya. ${ }^{22}$

Dalam aksi kejahatan yang terorganisasi tersebut sering mendapat sebutan khusus seperti kejahatan yang dilakukan oleh sindikat mafia. Cara kerjapun para mafia ini dilakukan secara terselubung atau hidden crime. Biasanya mafia ini merupakan jaringan gelap peredaran obat - obat berbahaya dari bahan narkotika dan psikotropika. ${ }^{23}$ Sindikat narkotika dan obat - obat berbahaya para pelaku yang

${ }^{19}$ Abintoro Prakoso, Hukum Penitensier, Aswaja Pressindo, Yogyakarta, 2019, h. 67

${ }^{20}$ Ibid

21 Tolib Effendy, , Tindak Pidana International / Di Dalam dan Di Luar Yurisdiksi Mahmakah Pidana International, Setara Press, Malang, 2019, h. 20 - 21

22 Tom Obokata, The Value of International Law In Combating Transnational Organized Crime in The Asia - Facific, Volume 7, Asian Journal of International Law, h. 41

${ }^{23}$ Satrio Putro Kolopita, Penegakan Hukum Atas Pidana Mati Terhadap Pelaku Tindak Pidana Narkotika, Jurnal Lex Crimen, Volume III, Nomor 4, Agustus 2013 
tertangkap tidak luput dari proses peradilan yang kebanyakan berakhir dengan penjatuhan pidana mati seperti di Indonesia dalam kasus Bali Nine oleh warga Australia, juga Fredy Budiman gembong narkotika kelas kakap yang telah dieksekusi mati.

Tindak pidana selain terorisme dan narkotika di Indonesia yang para pelaku dari kedua jenis kejahatan termasuk kejahatan serius atau kejahatan sangat luar biasa (extra ordinary crimes), kejahatan yang lagi satu ini yakni tindak pidana korupsi bagi Indonesia telah mengatur pula sanksi pidana mati seperti tersurat dalam Pasal 2 ayat (2) Undang - Undang Nomor 31 Tahun 1999 jo Undang - Undang Nomor 20 Tahun 2001 tentang Pemberantasan Tindak Pidana Korupsi menyiratkan bahwa : "Dalam hal tindak pidana korupsi sebagaimana dimaksud dalam ayat (1) dilakukan dalam keadaan tertentu pidana mati dapat dilakukan". Ketentuan Pasal 2 ayat (2) tersebut menimbullkan adanya ambiguitas norma hukumnya, tidak ada kejelasan / kepastian karena mengandung syarat dalam frase kata "dapat". Maka bagi para koruptor di Indonesia masih dapat lolos dari jeratan pidana mati. Hal ini tergantung diskresi hakim dalam menginterpretasikan rumusan pasal tersebut dalam Pasal 2 ayat 92). Sehingga banyak kalangan pengamat hukum menilai ketentuan pidana mati bagi koruptor di Indonesia hanya pajangan, tidak bertaring, dan tidak bisa menggigit mangsanya untuk mematikannya. ${ }^{24}$

Kelembagaan seperti Komisi Pemberantasan Korupsi (KPK) Indonesia yang terkenal garang meringkus pejabat - pejabat negara, penegak hukum, lembaga legislatif (anggota DPR yang melakukan perbuatan tercela korupsi ini ditunggu keberaniannya agar ada koruptor yang terpidananya di pidana mati, sebagai shok therapy penegakan hukum korupsi di Indonesia. ${ }^{25}$

Ada peneliti yang membandingkan penegakan hukum korupsi antara di Indonesia dengan Biro Anti Korupsi yang dimiliki oleh negara Brunei Darussalam, bahwa penegakan hukumnya lebih tegas, pelaku kejahatan korupsi disana ditangani dengan sigap serta sanksi pidananya sangat ditakuti, sehingga negaranya aman dari bahaya korupsi bila dibandingkan dengan Indonesia, para pejabat elit negara memberi contoh melakukan tindak pidana tidak terpuji seperti korupsi. ${ }^{26}$

Walaupun bagi Indonesia tetap masih ada 2 (dua) kubu antara kelompok retensionis (setuju) dengan konsep pidana mati dan kelompok penentang (abolisionis), namun negara melalui beberapa hukum positifnya tetap mencanangkan pidana mati ini. Kebijakan penal tersebut sebagai antipatif dari arus dimanisasi kejahatan yang muncul dengan berbagai modus dan type kejahatan yang kian hari penegak hukum selalu ketinggalan langkah dan kalah cepat dibanding para penjahat dengan model serta kepintarannya dalam menyembunyikan aksi jahatnya.

Kebijakan penal (criminal policy) di bidang terkait pidana mati mesti ke depan sinkron antara pencanangan jenis pidana (straaf soort) menyangkut kualifikasi delik, lama masa pidana (dalam hal ini masa tunggu) dari terpidana mati untuk dieksekusi

\footnotetext{
${ }^{24}$ Ridwan, Kebijakan Formulasi Hukum Pidana Dalam Penanggulangan Tindak Pidana Korupsi”, Dalam “ Kanun Jurnal Ilmu Hukum, Nomor 60 Tahun XV, Agustus 2013

${ }^{25}$ Abdul Kholik M., Eksistensi Komisi Pemberantasan Korupsi (KPK) Dalam Peradilan Korupsi di Indonesia, Artikel Dalam : Jurnal Hukum Fakultas Hukum Universitas Islam Indonesia (UII), Nomor 26, Volume 11, Tahun 2011

${ }^{26}$ Azhar, Peranan Biro Anti Korupsi Dalam Mencegah Terjadinya Korupsi di Brunei Darussalam, Artikel Dalam : Jurnal Litigasi Volume 10, Nomor 7 Fakultas Hukum Universitas Pasundan, Bandung, Tahun 2009
} 
(straaf mat) dari yang tidak kalah runyam serta menjadi sorotan menyangkut teknis eksekusi bagi terpidana mati (straaf modus). Selalu masih menjadi perdebatan panjang menyangkut sarana atau alat dengan teknis apa dan bagaimana mesti dilakukan dalam mengeksekusi terpidana mati tersebut Indonesia masih menggunakan dengan cara ditembak sampai mati oleh regu tembak. Banyak negara - negara maju yang masih menganut penerapan pidana mati ini menanggalkan dengan cara gaya lama seperti dengan digantung, dipenggal dengan senjata, ditembak, memakai gas, duduk di kursi listrik terpidananya, namun semua itu dipandang kurang manusiawi, masih menimbulkan rasa penderitaan, rasa sakit yang dirasakan oleh terpidana seperti Amerika Serikat (AS) yang kejahatan serius dalam mengeksekusi terpidananya telah memakai suntik mati dengan cairan kimia (lethal injection), cara ini banyak diikuti oleh negara - negara lain karena dipandang lebih manusiawi dan korbannya lebih singkat mengalami rasa sakitnya.

Berbeda dengan negara Italia sejak abad 14 hingga abad 15 memakai alat eksekusi berupa pisau lurus yang bernama "quiltotine", diikuti oleh negara Irlandia dan Scotlandia juga menggunakan senjata quiltotine ini, juga Swiss menggunakan senjata serupa bahkan menyebut quiltotine sebagai alat eksekusi asli Italia. ${ }^{27}$

\subsubsection{Justifikasi Filosofis - Ontologis, Sosio - Legal Cultural Konsepsi Pidana Penjara Seumur Hidup Versus Pidana Mati Bagi Indonesia}

Indonesia sebagai bentuk negara dengan landasan hukum (rechtstaat) dengan type penyelenggaraan negara untuk kesejahteraan (welfare states) seperti telah terpateri dalam Pembukaan UUD Negara Republik Indonesia Tahun 1945. Kesejahteraan dimaksudkan bukan kemakmuran materi belaka, namun lebih jauh dari itu agar dipenuhinya kepuasan lahir dan batin oleh negara melalui pemerintahannya oleh rakyat, dari rakyat dan untuk rakyat. Konsep pidana penjara seumur hidup bila diibaratkan seperti dua sisi mata uang, sulit ditemukan sisi - sisi perbedannya. Juga ibarat pepatah kata bila makan buah simalakama, dalam bahasa ilmiah dirangkai dengan suku kata "dillematis". Menjadi ungkapan yang cocok dan tepat bila memandang posisi / kedudukan pada fenomena penjatuhan sanksi antara pilihan yang mesti harus dipilih dari pidana penjara seumur hidup dengan pidana / hukuman mati tersebut.

Bila salah satu harus dipilih diantara dua, yang pasti akan menentukan pilihan itu bukan datangnya dari terdakwanya, namun ketetapan pilihan yang menentukan ada di tangan hakim sebagai wakilnya Tuhan di bumi. Terdakwa tinggal pasrah, puas tidak puas, terima tidak terima mesti harus terima, sekalipun taruhan terakhirnya mesti meregang nyawa. Berapa harga nyawa seorang manusia ? Sampai dunia kiamat dan orang sepintar malaikatpun tidak akan dapat memberi jawaban atas pertanyaan filsafat tersebut.

Negara bernafaskan hukum yang diberi jiwa dan darah oleh esensi etika, susila dan ajaran agama bagi tiap penganutnya. Kenapa pidana mati ataupun pidana hukum serta filosofi -filosofi ajaran agama kemudian dibungkus melalui dasar falsafah negara Pancasila yang Maha Agung dan Luhur sebagai pijakan berpikir berbuat dan brekata (Trikaya Parisuda - Versi Agama Hindu). Manusia mampu dan bisa berteori, tetapi sulit untuk menghindari larangan, itulah akhirnya manusia bisa keluar dari jalur

${ }^{27}$ Ebenezer Cobham Brewe and Marion Harland, Character Sketches of Romance Fiction and Drama, Journal Volume 2 The Nederlands, The Minerva Group, Inc. 2004, h. 128 
pemikiran normal dan akal sehat, akhirnya terjerumuslah mereka ke dalam kancah jurang kejahatan.

Bagi siapa saja yang telah berbuat kejahatan menurut Suratman dari ajaran beberapa agama adalah dibenarkan akan pidana mati untuk dijatuhkan pada pelakunya. hal tersebut tersurat dan tersurat sebagai berikut :"bagi mereka (antara lain: GEWIN) yang cenderung mempertahankan pidana mati dengan menari dalil dasar dari ajaran ke tuhanan, Mensitir dari: AL KITAB (Bijbeel) yaitu kejadian (Genesis) 9:6 dan Roma (Romeinen 13:4 secara berdampingan yang berbunyi: “siapa yang menumpahkan darah manusia darahnya akan tertumpah oleh manusia, sebaba Allah membuat manusia itu menurut gambarnya sendiri?? karena pemerintah adalah hamba allah untuk kebaikan mu. tetapi jika engkau berbuat jahat takutlah akan dia, karena tidak percuma pemerintah menyandang pedang. pemerintah adalah hamba allah untuk membalaskan mereka allah atas mereka yang berbuat jahat?? dari firman ini diambil kesimpulan, bahwa pidana mati dibenarkan adanya. ${ }^{28}$

Di dalam al-qur'an dikenal juga adanya ketentuan mengenai pidana mati di surah al-maidah ayat 45 dan surah al-isra ayat 33 di sebutkan antara lain yang tafsirnya berbunyi:" hai orang-orang yang beriman diwajibkan atas kamu qisaash berkenaan dengan orang yang dibunuh;...... dan seterusnya, Qishaas adalah mengambil pembalasan yang sama, Qishaas tidak dilakukan, jika ahli waris dari orang yang dibunuh memaafkan pembunuh, akan tetapi pembunuh tersebut harus membayar ganti rugi yang disebut dia "dari kami telah mentapkan terhadap mereka di dalam Taurat") bahwasannya jiwa dibalas jiwa, mata dengan mata, hidung dengan hidung........ dan seterusnya. ${ }^{29}$

Dari ajaran agama hindu sebagaimana dapat dibaca dari terjemahan Manawa Dharmasastra atau Manusia Dharma Sastra atau Weda Smrti (Compendium Hukum Hindu) Usaha Penulisan G. Pudja MA dan TjokordaRai Sudhartama MA Cetakan Ke-5 Tahun 1977 * 1978 mengenai pidana mati sebagai berikut :

a. Buku VIII Pasal 34 (hlm 425) : "Barang milik yang hilang kemudian didapatkan kembali oleh pegawai pemerintah akan ditaruh dalam simpanan penjabat-penjabat (khusus); ia yang dapat dibutuhkan bersalah mencuri dapat dihukum mati dengan memakai seekor gajah"

b. Buku VIII Pasal 32 (hlm. 503) : "Bagi orang - orang yang mencuri dari keluarga keluarga baik, terutama wanita dan permata yang terbaik, yang bersalah layak mendapat hukuman badan atau hukuman mati".

c. Buku VIII Pasal 359 (hlm. 511) : “.... diancam dengan hukuman mati karena perbuatan berzinah..."

d. Buku VIII Pasal 379 (hlm. 516) : “... tetapi laki-laki dari golongan lain akan dihukum hukuman mati".

Dari paparan ketiga agama (Kristen, Islam, Hindu) tersebut diatas dalam masing-masing ajarannya menyaratkan bahwa ada landasan hukum pembenar bahwa pelaku tindak pidana atas perbuatan - perbuatan dimaksud masing-masing dapat dipidana mati. ${ }^{30}$

28S. R. Sianturi, Asas - Asas Hukum Pidana di Indonesia dan Penerapannya, Penerbit Alumni AHAEM - PETEHAEM, Jakarta, 1986, h. 463

${ }^{29} \mathrm{Ibid}$

30Ibid, h. 464 
Juga keberadaan sanksi pidana mati dalam hukum positif Indonesia diatur dan dibenarkan mulai dari Undang - Undang Dasar Negara Republik Indonesia Tahun 1945 (tidak bertentangan dengan konstitusi Nomor : 2-3/PUU-V/2007/MK. KUHP melalui Pasal 10 dan ada 8 Pasal mengatur sanksi pidana mati seperti dalam : KUH Militer, Undang - Undang Nomor : 12/1951 tentang Senjata Api, Undang - Undang Nomor : 31/PNPS/1964 tentang Tenaga Atom, Undang - Undang Nomor : 5/1997 tentang Psikotropika, Undang - Undang Nomor 35/2009 tentang Narkotika, Undang Undang Nomor 31 / 1999 tentang Pengadilan HAM, Undang - Undang Nomor 35 / 2014 tentang Perlindungan Anak dan Undang - Undang Nomor 15 Tahun 2003 jo Undang - Undang Nomor 5 Tahun 2018 tentang Teorisme, Perpu Nomor : 21/1959 tentang Memperberat Ancaman Hukuman Terhadap Tindak Pidana Ekonomi.

Perspeketif cultural sejarah di Indonesia sejak jaman kerajaan (sebelum datangnya penjajah) pidana mati telah diterapkan bahkan eksekusi matinya dilakukan dengan cara - cara kejam dan tidak manusiawi, bahkan dilakukan di muka umum.

\section{KESIMPULAN}

Penjatuhan sanksi pidana penjara seumur hidup menjadi altermatif (pengganti) dari pidana mati (hukuman mati) ada beberapa justifikasi pertimbangan seperti pidana mati yang sudah dieksekusi bila nantinya terbukti ada kekhilafan / kehirauan hakim dalam memutus dengan pidana mati maka nasib terpidana tidak dapat dikoreksi lagi karena nyawa sudah dicabut. Pidana mati pertentangan dengan hak untuk hidup tiap individu pidana mati melanggar prinsip HAM sebagai hak kodrati dan alamiah yang terlalu diberikan Tuhan selalu pencipta segala kehidupan di bumi termasuk nyawa manusia, pidana mati bertentangan dengan prinsip atau generasi 1 , derogable light hak hidup tidak dapat dicabut oleh siapapun termasuk negara, maka alternatifnya pidana mati dapat digantikan dengan pidana mati dapat digantikan dengan pidana penjara seumur hidup walaupun penderitaan fisik dan psikis tetap melekat pada diri terpidana sebagai konsekuensi logis atas pertanggung jawaban hukum pelaku tindak pidana serius maka terpidana mati menerima sanksi pidana seberat apapun dirasakan terpidana guna dapat merenungkan akibat perbuatan yang dialami korban, agar sesuai dengan prinsip keseimbangan dalam hukum pidana yakini daad - dader - strafreeht (perbuatan - pelaku - sanksi - hukumannya) guna terwujudnya keadilan - kemanfaatan dan kepastian hukum.

Hendaknya bagi hukum selektif dalam menjatuhkan pidana hukum kemerdekaan jangka panjang maupun pidana mati tetap mempertimbangkan sifat dan modus tindak pidana yang luar biasa (extra ordinary crime)

\section{DAFTAR PUSTAKA}

\section{Buku}

Achmad Ali, Menguak Realitas Hukum, Prenada Media Group, Jakarta, 2008

Abintoro Prakoso, Hukum Penitensier, Aswaja Pressindo, Yogyakarta, 2019

Barda Nawawi Arief, Bunga Rampai Kebijakan Hukum Pidana, PT. Citra Aditya Bakati, Bandung, 2002

Herbert L. Packer, The Limits of Criminal Sanction, Stamford University, California, 1968

I Made Pasek Diantha. Metodologi Penelitian Hukum Normatif dalam Justifikasi Teori Hukum. Jakarta: Prenada Media Group, 2017

Muladi, Demokratisasi, Hak Asas Manusia dan Reformasi Hukum di Indonesia, The Habibie Centre, Jakarta, 2002

Peter Mahmud Marzuki. Penelitian Hukum. Jakarta: Kencana Prenida Media, 2011 
Roeslan Saleh (I), Masalah Pidana Mati, Aksara Baru, Jakarta, 1978

Roeslan Saleh (II), Stelsel Pidana Indonesia, Aksara Baru, Jakarta, 1983

Sue Titus Reid, Criminal Justice Procedure and Issues, West - Publishing Company, New York, 1978

S. R. Sianturi, Asas - Asas Hukum Pidana di Indonesia dan Penerapannya, Penerbit Alumni AHAEM - PETEHAEM, Jakarta, 1986

Tolib Effendy, Tindak Pidana International / Di Dalam dan Di Luar Yurisdiksi Mahmakah Pidana International, Setara Press, Malang, 2019

\section{Jurnal atau Seminar Nasional}

Abdul Kholik M., Eksistensi Komisi Pemberantasan Korupsi (KPK) Dalam Peradilan Korupsi di Indonesia, Artikel Dalam : Jurnal Hukum Fakultas Hukum Universitas Islam Indonesia (UII), Nomor 26, Volume 11, Tahun 2011

Azhar, Peranan Biro Anti Korupsi Dalam Mencegah Terjadinya Korupsi di Brunei Darussalam, Artikel Dalam : Jurnal Litigasi Volume 10, Nomor 7 Fakultas Hukum Universitas Pasundan, Bandung, Tahun 2009

B. Richard, The Experience of Long Trem Imprissionment, British Journal of Criminology, Vol. 18, No. 2, 1978

Heiner Bielefeldt, "Hak Asasi Manusia : Benturan Antara Barat dan Islam", dalam Jurnal : Wacana Hak Asasi Manusia Antara Skenario Kemanusiaan dan Proyek Global, Edisi 8, Tahun II, Inssit. Press, Yogyakarta,

Ebenezer Cobham Brewe and Marion Harland, Character Sketches of Romance Fiction and Drama, Journal Volume 2 The Nederlands, The Minerva Group, Inc. 2004

Jurnal Transisi, Media Penguatan Demokrasi Lokal, Edisi Nomor : 10/2015, ISSN : 1978 - 4287,Penerbit Instrans Instituete.

Kuat Yudi Prayitno, Restorative Justice Untuk Peradilan di Indonesia (Perspektif Yuridis Filosofis Dalam Penegakan Hukum In Conkreto), dalam : Jurnal Dinamika Hukum, Volume 12 Nomor 3, September 2012

Ridwan, Kebijakan Formulasi Hukum Pidana Dalam Penanggulangan Tindak Pidana Korupsi", Dalam “ Kanun Jurnal Ilmu Hukum, Nomor 60 Tahun XV, Agustus 2013

Satrio Putro Kolopita, Penegakan Hukum Atas Pidana Mati Terhadap Pelaku Tindak Pidana Narkotika, Jurnal Lex Crimen, Volume III, Nomor 4, Agustus 2013

Supanji, Hendarman, Eksistensi Pidana Mati Dalam Proses Penegakan Hukum di Indonesia, Jurnal Kajian Wilayah Eropa, Volume IV, Nomor 2 Tahun 2008

Tom Obokata, The Value of International Law In Combating Transnational Organized Crime in The Asia - Facific, Volume 7, Asian Journal of International Law,

Woro, Winandi dan Indra Rukmana Lukito, Penjatuhan Pidana Mati Dalam Tindak Pidana Narkotika, Jurnal Hukum, Volume XIX Nomor 19, 2010

\section{Peraturan Perundang - Undangan}

Undang - Undang RI Nomor 26 Tahun 2000 tentang Pengadilan Hak Asasi Manusia (HAM)

Undang - Undang RI Nomor 22 tahun 2002 jo Undang - Undang RI Nomor 5 Tahun 2010 tentang Grasi

Undang - Undang RI Nomor 31 tahun 1999 jo Undang - Undang RI Nomor 20 Tahun 2001 tentang Pemberantasan Tindak Pidana Korupsi

Undang - Undang RI Nomor 12 Tahun 1951 tentang Senjata Api

Undang - Undang RI Nomor 31 Tahun 1964 tentang Tenaga Atom 
Undang - Undang RI Nomor 5 Tahun 1997 tentang Psikotropika

Undang - Undang RI Nomor 35 Tahun 2009 tentang Narkotika

Undang - Undang RI Nomor 31 Tahun 1999 tentang Pengadilan HAM

Undang - Undang RI Nomor 35 Tahun 2014 tentang Perlindungan Anak

Undang - Undang RI Nomor 15 Tahun 2003 jo Undang - Undang Nomor 5 Tahun 2018

tentang Teorisme 